P-ISSN 2580 - 7781

E-ISSN 2615 - 3238

\title{
PEMANFAATAN RUANG TERBUKA HIJAU (RTH) MELALUI PEMBERDAYAAN USAHA MIKRO KECIL DAN MENENGAH OLEH PEMERINTAH DAERAH
}

\section{UTILIZATION OF GREEN OPEN SPACE (RTH) THROUGH EMPOWERMENT OF SMALL AND MEDIUM MICRO ENTERPROSES BY REGIONAL GOVERNMENTS}

\author{
Nina Sa'idah Fitriyah ${ }^{1)}$, Adi Purwanto ${ }^{2)}$ \\ ${ }^{1}$ Administrasi Publik, Fakultas Ilmu Sosial dan Ilmu Politik, \\ Universitas Abdurachman Saleh \\ ${ }^{2}$ Dinas Perumahan dan Kawasan Permukiman Situbondo \\ Email : ${ }^{1}$ ninafitriyah29@gmail.com
}

\begin{abstract}
ABSTRAK
Ruang terbuka hijau publik merupakan ruang terbuka yang dimiliki dan dikelola oleh pemerintah daerah kota yang digunakan untuk kepentingan masyarakat secara umum. Merujuk pada peraturan dan fenomena sehingga penelitian ini dirasa penting karena sarana dan prasana pemerintahan Kabupaten Situbondo membangun ruang terbuka hijau dapat termanfaatkan dengan baik oleh masyarakat melalui memberdayakan UMKM masyarakat yang ada disekitar lahan tersebut. Jenis penelitian ini menggunakan penelitian deskriptif dengan metode pendekatan kualitatif. Lokasi penelitian di Kecamatan Kapongan Kabupaten Situbondo Jawa Timur. Teknik penentu informan menggunakan purposive sampling. Teknik pengumpulan data menggunakan wawancara mendalam, observasi dan study pustaka. Hasil penelitian ini menunjukkan bahwa pemanfaatan Ruang Terbuka Hijau (RTH) di Desa Kesambirampak Kecamatan Kapongan Kabupaten Situbondo sebagai berikut : 1) Segi Bidang Pendidikan yakni menduduki posisi penting dalam proses dinamika pertemuan budaya, karena melalui ruang ini dihubungkan jalinan budaya antara wilayah dan sebagai aicon desa untuk mengenal budaya desa tersebut. Dari sinilah interaksi budaya dengan segala implikasinya terjadi. Interaksi budaya ini telah memunculkan kelompok-kelompok sosial dari berbagai etnis dan membentuk kampung-kampung etnis tertentu dengan kulturasi budaya mereka yang berkembang di sekitar taman. 2) Segi Bidang Ekonomi yakni dapat meningkatakn pendapatan warga masyarakat sekitar sehingga dapat menambah pula terhadap Pendapat Asli Desa (PAD) yang berdampak pada kesejahteraan masyarakat. 3). Segi Bidang Sosial yakni sebagai wadah berkumpulnya manusia dalam melakukan segala bentuk kegiatan sehingga menghasilkan interaksi dan komunikasi antar warga sebagai wadah rekreasi keluarga yang sangat terjangkau oleh masyarakat.
\end{abstract}

Kata Kunci: RTH, Pemberdayaan, UMKM, Pemerintah Daerah

\begin{abstract}
Public green open space is an open space that is owned and managed by the city government which is used for the benefit of the community in general. Referring to regulations and phenomena so that this research is considered important because the government facilities and infrastructure of Situbondo Regency to build green open spaces can be utilized well by the community by empowering the community MSMEs around the land. This type of research uses descriptive research with a qualitative approach method. The research location is in Kapongan District, Situbondo Regency, East Java. The technique of determining informants uses purposive sampling. The types of data used are
\end{abstract}


P-ISSN $2580-7781$

E-ISSN 2615 - 3238

secondary and primary data. Data collection techniques using in-depth interviews, observation and literature study. The results of this study indicate that the use of Green Open Space (RTH) in Kesambirampak Village, Kapongan District, Situbondo Regency is as follows: 1) In terms of the Education Sector, namely occupying an important position in the dynamic process of cultural encounters, because through this space the cultural linkages between the region and as a village aicon to get to know the village culture. This is where the cultural interaction with all its implications occurs. This cultural interaction has created social groups from various ethnicities and formed certain ethnic villages with their cultural culture that has developed around the park. 2) In terms of the economic sector, namely that it can increase the income of the surrounding community members so that it can also increase the Village Original Opinion (PAD) which has an impact on the welfare of the community. 3). In terms of the social field, namely as a forum for human gathering in carrying out all forms of activities so as to produce interaction and communication between residents as a place for family recreation that is very affordable to the community.

Keywords: RTH, Empowerment, UMKM, Local Government

\section{PENDAHULUAN}

Industri yang didukung dengan kemajuan ilmu pengetahuan dan teknologi diyakini mampu membawa manusia menuju tingkat kesejahteraan yang lebih tinggi. Kemajuan tersebut nyatanya juga memberikan suatu permasalahan baru yang perlu menjadi perhatian besar setiap kalangan. Permasalahan lingkungan yang terjadi juga banyak disebabkan dari berbagai kegiatan manusia. Kegiatan manusia yang tidak memperhatikan keberlanjutan lingkungan akan membawa kerusakan, misalnya seperti membuang sampah dan limbah sembarangan, pemborosan energi, penebangan liar, dan lain sebagainya.

Kesadaran pemerintah dan masyarakat terhadap lingkungan terus dikembangkan. Berbagai program untuk meningkatkan kualitas lingkungan mulai digerakkan untuk menghindari kerusakan kota di masa depan. Pengelolaan fisik lingkungan kota diwujudkan pemerintah melalui program-program yang bertujuan meningkatkan keberlanjutan lingkungan kota. Berkelanjutan yang dimaksud adalah adanya keseimbangan baik secara ekonomi, sosial maupun lingkungan alam atau lebih dikenal dengan istilah sustainable city menurut (Budihardjo, 2012).

Sustainable City merupakan bentuk dari Sustainable Development yakni pembangunan yang berguna untuk memenuhi kebutuhan saat ini tanpa perlu menurunkan kemampuan generasi yang akan datang. Pembangunan kota yang berkelanjutan tidak hanya didasarkan atas aspek lingkungan yang berkelanjutan 
P-ISSN $2580-7781$

E-ISSN 2615 - 3238

melainkan bersumber dari masyarakat berkelanjutan. Berkelanjutan memiliki makna terjaga secara stabil kondisi ekonomi masyarakat yang sejahtera sesuai dengan pengembangan potensi lingkungan atau keunikan masyarakatnya serta kondisi lingkungan alam yang semakin baik. Sehingga dapat disimpulkan bahwa kota yang berkelanjutan adalah kota yang mampu menjaga keseimbangan lingkungan (ecology), ekonomi (economy) dan sosial masyarakat (social) (Budihardjo, 2012).

Salah satu program yang dilakukan pemerintah dalam menciptakan keberlanjutan lingkungan adalah melalui P2KH (Program Pengembangan Kota Hijau) dengan pengembangan pembangunan Ruang Terbuka Hijau Kawasan Perkotaan (RTHKP). Pembangunan RTHKP berupa Hutan Kota, Jalur Hijau Kota, Taman Kota, Taman Wisata, Tempat Pemakaman, pekarangan, pertanian dan perkebunan. Pengembangan RTH sesuai dengan Undang-undang Nomor 26 Tahun 2007 pasal 29 tentang Penataan Ruang telah menetapkan Ruang Terbuka Hijau (RTH) terdiri dari RTH Publik dan RTH Privat. Komposisi RTH daerah adalah 30 persen dari keseluruhan kota dengan proposisi terdiri dari RTH publik (20 persen) dan RTH privat (10 persen) dari Luar keseluruha Kota. Menurut Dinas Perumahan dan Kawasan Permukiman Kabupaten Situbondo keberadaan RTH publik di Kabupaten Situbondo belum memenuhi 20 persen namun privat keberadaannya lebih dari 10 persen.

Hal itu dikarenakan karakteristik penggunaan lahan dan karakteristik kepadatan tinggi yang dimiliki Kabupaten Situbondo, jumlah penduduk sebesar 687.099 jiwa dengan luas wilayah 163.850 Ha. Salah satu dari 17 Kecamatan di Kabupaten Situbondo yaitu Kecamatan Kapongan jumlah kepadatan penduduk 41.265 jiwa dengan luas wilayah 44,54 $\mathrm{Km}^{2}$ terdiri dari 10 Desa, memiliki 30 wisata alam dan 100 usaha menengah kecil masyarakat (UMKM) dalam menunjang perekonomian masyarakat. Kecamatan Kapongan mempunyai RTH yaitu "Taman Lanceng", yang terdapat ditengah-tengah permukiman penduduk yang padat dan harapan pemerintah dapat memberikan manfaat terhadap perkembangan perekonomian masyarakat dan budaya lokal. Dengan ditunjang fasilitas yang ada di RTH antara lain cafe, kios, parkir, toilet, tempat bermain anak serta jajanan 
P-ISSN $2580-7781$

E-ISSN 2615 - 3238

traditional sebagai daya tarik masyarakat untuk datang atau melakukan kegiatan di RTH bersama keluarga. Hal inilah menjadi fenomena menarik dalam pemanfaatan RTH mengingat karakteristik permukiman daerah tersebut yaitu permukiman kepadatan tinggi. Kepadatan bangunan juga menunjukkan keseragaman, dan mayoritas menggambarkan suatu kawasan permukiman yang padat. Untuk mencegah terbentuknya permukiman padat di kawasan ini, perlu dilakukan pemetaan guna lahan, terutama kuantitas dan kualitas ruang terbukanya (open space), sehingga ruang terbuka hijai yang telah dibangun pemerintah dapat dimanfaatkan oleh pelaku usaha untuk meningkatkan kesejahteraan masyarakat.

Berdasarkan deskripsi di atas maka rumusan masalah dalam penelitian ini adalah menggambarkan bagaimana pemanfaatan ruang terbuka hijau melalui pemberdayaan usaha mikro kecil dan menengah masyarakat di RTH Kecamatan Kapongan ?. Tujuan penelitian ini adalah mengkaji pola pemanfaatan ruang berdasarkan kebutuhan dan pola aktivitas yang dilakukan didalamnya dengan melibatkan UMKM di Kecamatan tersebut untuk menarik masyarakat datang ketempat tersebut.

\section{METODE PENELITIAN}

Penelitian ini menggunakan metode penelitian deskriptif kualitatif. Lokasi penelitian adalah Kabupaten Situbondo Kecamatan Kapongan Desa Kesambirampak yang dikelolah oleh Forum Komunikasi Informasi Masyarakat (FKIM) yang didampingi oleh BUMDesa Kesambirampak. Waktu penelitian dilaksanakan pada Januari 2020 sampai selesai. Jumlah informan dalam penelitian kualitatif lebih tepat dilakukan sengaja (purposive) dan tidak dipersoalkan jumlahnya (Bungin, 2006). Key person dalam penelitian ini adalah Perwakilan dari Dinas Perumahan dan Kawasan Permukiman Kabupaten Situbondo serta yang menangani pengelolaan pada RTH Taman Lanceng Kecamatan Kapongan. Informan selanjutnya menggunakan snowball sampling yang ditunjukkan oleh key person Pengumpulan data dilakukan dengan wawancara, observasi dan studi dokumen. Model analisis data dalam penelitian ini menggunakan model interaktif oleh Miles dan Huberman. Aktivitas dalam analisis data, yaitu data reduction, data 
P-ISSN $2580-7781$

E-ISSN 2615 - 3238

display, dan conclusion drawing/verification. Langkah-langkah dalam tahap reduksi antara lain. Reduksi data dilakukan dengan merangkum, memilih hal-hal pokok, memfokuskan pada hal-hal yang penting. Dengan demikian data yang telah direduksi memberikan gambaran yang lebih jelas, dan mempermudah peneliti untuk melakukan pengumpulan data selanjutnya. Langkah selanjutnya adalah penyajian data. Penyajian data dalam penelitian ini adalah dengan teks yang bersifat naratif. Dengan mendisplaykan data, maka memudahkan peneliti untuk memahami apa yang terjadi dan merencanakan kerja selanjutnya berdasarkan apa yang telah dipahami. Selanjutnya adalah menarik kesimpulan awal. Kesimpulan awal yang dikemukakan masih bersifat sementara dan akan berubah bila tidak ditemukan bukti-bukti yang kuat. Teknik uji keabsahan data menggunakan triangulasi sumber sebagai teknik pengecekkan kredibilitas (derajat kepercayaan) data. Proses keteralihan dilakukan peneliti dengan uraian rinci dimana peneliti mencocokkan temuantemuan penelitian dengan data yang diperoleh lewat rekaman atau wawancara dan hasil dokumentasi.

\section{HASIL PENELITIAN DAN PEMBAHASAN}

Ruang Terbuka Hijau (RTH) merupakan ruang yang direncanakan karena kebutuhan akan tempat-tempat pertemuan dan aktivitas bersama di udara terbuka. Ruang Terbuka (open Space), Ruang Terbuka Hijau (RTH), Ruang Publik (Public space). Ruang Terbuka berfungsi sebagai wadah untuk kehidupan manusia, baik secara individu maupun kelompok, serta wadah makhluk lainnya untuk hidup dan berkembang secara berkelanjutan. Suatu wadah yang menampung aktivitas manusia dalam suatu lingkungan yang tidak mepunyai penutup dalam bentuk fisik. Ruang yang berfungsi antara lain tempat bermain aktif untuk anak-anak dan dewasa, tempat bersantai pasif untuk orang dewasa, sebagai areal konservasi lingkungan hijau. Adapun proses perencanaan pembangunan RTH sebagaimana gambar dibawah ini :

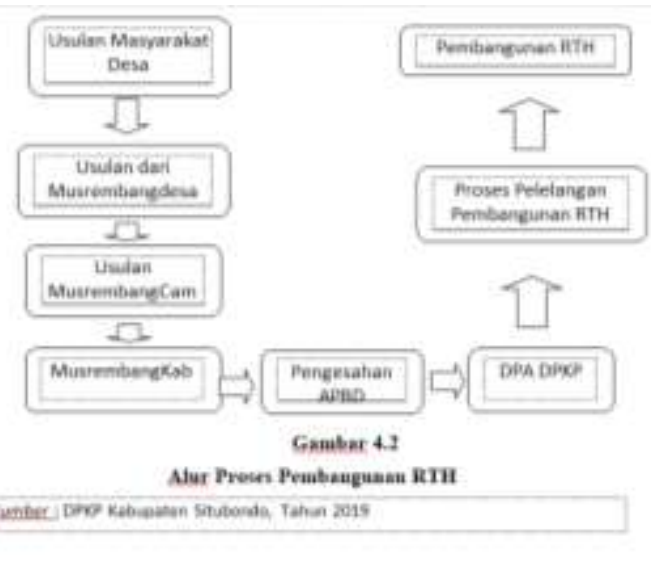




\section{Sasaran dan Tujuan Pembangunan Ruang Terbuka Hijau (RTH)}

Berdasarkan Peraturan Menteri Dalam Negeri Nomor 1 Tahun 2007 tentang Penataan Ruang Terbuka Hijau Kawasan Perkotaan; serta Peraturan Menteri Pekerjaan Umum Nomor : 05/ Prt/ M/ 2008 Tentang Pedoman Penyediaan Dan Pemanfaatan Ruang Terbuka Hijau Di Kawasan Perkotaan.Tujuan pembangunan RTH pada prinsipnya adalah untuk menjaga keseimbangan ekosistem di wilayah kota.Lebih lanjut berdasarkan Pasal 2 Permendagri RTHKP, tujuan penataan RTHKP adalah:

1. Menjaga keserasian dan keseimbangan ekosistem lingkungan perkotaan.

2. Mewujudkan kesimbangan antara lingkungan alam dan lingkungan buatan di perkotaan.

3. Meningkatkan kualitas lingkungan perkotaan yang sehat, indah, bersih dan nyaman.

Ruang Terbuka Hijau (RTH) baik RTH publik maupun RTH privat, memiliki fungsi utama (intrinsik) yaitu fungsi ekologis, dan fungsi tambahan (ekstrinsik) yaitu fungsi arsitektural, sosial, dan fungsi ekonomi. Dalam suatu wilayah perkotaan empat fungsi utama ini dapat dikombinasikan sesuai dengan kebutuhan, kepentingan, dan keberlanjutan kota. Berbagai fungsi yang terkait dengan keberadaanya (fungsi ekologis, sosial, ekonomi, dan arsitektural) dan nilai estetika yang dimilikinya (obyek dan lingkungan) tidak hanya dapat meningkatkan kualitas lingkungan dan untuk kelangsungan kehidupan perkotaan tetapi dapat menjadi nilai kebanggaan dan identitas kota.

RTH berfungsi ekologis, yang menjamin keberlanjutan suatu wilayah kota secara fisik, harus merupakan satu bentuk RTH yang berlokasi, berukuran, dan berbentuk pasti dalam suatu wilayah kota, seperti RTH untuk perlindungan sumberdaya penyangga kehidupan manusia dan untuk membangun jejaring 
P-ISSN $2580-7781$

E-ISSN 2615 - 3238

habitat hidupan liar. RTH untuk fungsi-fungsi lainnya (sosial, ekonomi, arsitektural) merupakan RTH pendukung dan penambah nilai kualitas lingkungan dan budaya kota tersebut, sehingga dapat berlokasi dan berbentuk sesuai dengan kebutuhan dan kepentingannya, seperti untuk keindahan, rekreasi, dan pendukung arsitektur kota .

Manfaat RTH berdasarkan fungsinya dibagi atas manfaat langsung (dalam pengertian cepat dan bersifat tangible) seperti mendapatkan bahan-bahan untuk dijual (kayu, daun, bunga), kenyamanan fisik (teduh, segar), keinginan dan manfaat tidak langsung (berjangka panjang dan bersifat intangible) seperti perlindungan tata air dan konservasi hayati atau keanekaragaman hayati .

Sedangkan di dalam Pasal 4 Permen RTHKP, manfaat RTHKP adalah: sarana untuk mencerminkan identitas daerah; sarana penelitian, pendidikan dan penyuluhan; sarana rekreasi aktif dan pasif serta interkasi sosial; meningkatkan nilai ekonomi lahan perkotaan; menumbuhkan rasa bangga dan meningkatkan prestise daerah; sarana aktivitas sosial bagi anak-anak, remaja, dewasa dan manula; sarana ruang evakuasi untuk keadaan darurat; memperbaiki iklim mikro; dan meningkatkan cadangan oksigen di perkotaan.

Sebagaimana hasil wawancara Bapak Ir. H Eko Prayudi selaku Kepala Dinas Perumahan dan Kawasan Permukiman pada wawancara tanggal 02 Juli 2020, pukul 09.15 WIB bertempat di ruang kepala Dinas Perumahan dan Kawasan Permukiman Kabupaten Situbondo:

"Tujuan pembangunan RTH untuk memenuhi kebutuhan masyarakat sekitar yang mana awal mula lahan tersebut tidak termanfaatkan sehingga ada usulan dari masyarakat untuk dibuat taman sebagai tempat alternatif masyarakat/warga berekreasi bersama keluarga. Juga sebagai lahan jualan bagi warga yang tidak bekerja sehingga dapat meningkatkan pendapatan keluarga mereka dalam memenuhi kebutuhan hidup"

Menurut Bapak Legiono selaku Kepala Desa pada wawancara pada tanggal 17 Juli 2020, pukul 08.30 WIB bertempat di Kantor Balai Desa Kesambirampak Kecamatan Kapongan Kabupaten Situbondo: 
P-ISSN $2580-7781$

E-ISSN 2615 - 3238

"Sasaran dan tujuannya menurut saya sudah tepat sasaran. Kalo tujuan lebih menekan pada perekonomian masyarakat sehingga warga saya dapat merasakan keberadaan bangunan RTH dengan berjualan segala macam makanan baik itu jajanan traditional maupun makanan siap saji di Taman tersebut."

Masyarakat juga menjelaskan kalau tujuan Ruang Terbuka Hijau (RTH) taman lanceng Kecamatan Kapongan Desa Kesambirampak itu sangatlah berguna untuk masyarakat. Masyarakat juga menjelaskan bahwa sasaran Ruang Terbuka Hijau (RTH) sudah tepat sasarannya, yang mana yang datang ke taman tersebut masyarakat Kabupaten Situbondo terutama warga sekitar taman tersebut serta pedagang kaki lima mayoritas warga Desa Kesanbirampak. Serta para warga yang tidak bekerja yang ingin berjualan. Seperti yang dikatakan oleh Bapak Gafur selaku ketua paguyuban pedagang di taman lanceng Desa Kesambirampak Kecamatan Kapongan pada wawancara tanggal 18 Juli 2020 pukul 10.25 WIB bertempat di Rumah :

"Sudah tepat. Karena sasarannya masyarakat serta penataan PKL yang ada disekitaran lapangan yang sekarang menjadi taman lanceng. Yang saya tau tujuannya sendiri penataaan kota dari pedang kaki lima yang ada dipinggir lapangan sehingga menjadi indah dan menarik, maka dibangunkan taman oleh pemerintah harapannya sebagai tempat rekreasi, bermain anak-anak dan tempat jualan warga sekitar dalam mendukung perekonomian rumah tangganya, hanya saja fasilitas yang ada belum memenuhi seperti tempat bermain anak harus berbayar, kondisi taman ramai ketika malam sabtu - malam senin saja. Ada ivent sendiri kita mengenalkan jajanan traditional dan menampilkan budaya masyarakat sekitar."

Hal senada juga dijelaskan oleh Ibu Suyati selaku masyarakat yang berkunjung di Taman lanceng Kecamatan Kapongan pada wawancara tanggal 18 Juli 2020, pukul 18.30 WIB bertempat di Rumah kediamannya:

"Sudah tepat pak. Yang saya tahu tujuannya memberikan tempat untuk berekreasi secara gratis agar terjangkau bagi kalangan kayak kita.Contohnya seperti anak dapat bermain setelah 1 minggu full mereka sekolah.” 
P-ISSN $2580-7781$

E-ISSN 2615 - 3238

Dan menurut Bapak Agus Purnomo selaku masyarakat/warga sekitar taman pada wawancara tanggal 18 Juli 2020, pukul 19.30 WIB di lokasi Ruang Terbuka Hijau:

"Kalau sasarannya sendiri menurut saya sendiri sudah tepat yaitu masyarakat seperti kami. Untuk tujuan jelas memberikan pelayanan kepada kami, karena selain sebagai tempat bermain anak-anak, interaksi sesama masyarakat, perekonomian juga ada pelayanan dari pemerintah yaitu Simpel Puter (mulai dari E-KTP, KK, Akte kelahiran, pembayaran pajak kendaraan dll). Sangat bagus pak jadi kita tidak usah menunggu dipagi hari untuk mengurus keperluan itu semua sehingga tidak menggangu waktu kerja kita dan selesainya lebih cepat dari pada datang ke instansi yang ngurusi keperluan tersebut".

Berdasarkan hasil wawancara pada informan tentang sepengetahuan mereka tentang Ruang Terbuka Hijau (RTH) taman lancing Desa Kesambirampak Kecamatan Kapongan. Tujuan dari program yang ada di Ruang Terbuka Hijau (RTH) ini telah diketahui oleh masyarakat, bahwa Ruang Terbuka Hijau (RTH) sangat bermanfaat bagi masyarakat. Dengan menggunakan metode mezzo yakni memberdayakan masyarakat melalui UMKM yang dinamai Forum Komunikasi Informasi Masyarakat (FKIM) yang dikelolah oleh Badan Usaha Milik Desa (BUMDesa) sebagai penadapatan Desa pada khususnya untuk kemajuan perekonomian masayarakat. Sasaran program yang ada di Ruang Terbuka Hijau (RTH) juga sudah tepat sasaran. Jadi dapat disimpulkan bahwa tujuan dan sasaran dari pembangunan Ruang Terbuka Hijau (RTH) telah tercapai.

\section{Pemanfaatan Ruang Terbuka Hijau (RTH)}

Pembangunan Ruang Terbuka Hijau (RTH) merupakan suatu bentuk kegiatan pemerintah yang diprioritaskan untuk masyarakat khususnya bidang sosial maupun ekonomi. Pemerintah telah menetapkan sasaran-sasaran dan tujuan yang akan hendak dicapai dalam pembangunan Ruang Terbuka Hijau (RTH) ini.

Suatu program kegiatan pemerintah memiliki strategi khusus untuk mencapai tujuan yang telah ditentukan, begitu juga dengan pemanfaatan Ruang 
P-ISSN $2580-7781$

E-ISSN 2615 - 3238

Terbuka Hijau (RTH) taman lancing Desa Kesambirampak Kecamatan Kapongan dalam rangka mempersiapkan kunjungan wisata di Kabupaten Situbondo. Dinas Perumahan dan Kawasan Permukiman memiliki strategi dalam pencapaian pemanfaatan pembangunan Ruang Terbuka Hijau (RTH) yaitu melakukan sosialiasasi kepada masyarakat melalui Ketua RT, tokoh masyarakat serta kelompok pedagang yg sejak awal berjualan ditempat tersebut. Contoh sosialisasinya seperti memberikan pemahaman kepada masyarakat tentang apa itu Ruang Terbuka Hijau (RTH). Seperti halnya yang telah disampaikan oleh Ali Munir selaku kepala bidang pertamanan dan PJU yang bertempat di Kecamatan Kapongan Kabupaten Situbondo dalam kegiatan sosialisasi:

"Dalam pembangunan Ruang Terbuka Hijau diusulkan oleh desa lewat MusrembangDes dengan harapan lahan kosong dapat dimanfaatkan menjadi taman serta penataan PKL yang berjualan sekitar lahan tersebut, kemudian diusulkan ke MusrembangCam selanjutnya diusulkan pada MusrembangKab dan masuk dalam usulan kegiatan Dinas Perumahan dan Kawasan Permukiman. Setelah disahkan dan dianggarkan dalam APBD Dinas maka kegiatan tersebut menjadi program pada tahun usulan yaitu pada tahun 2015. Kemudian dibangunlah Ruang Terbuka hijau oleh kontraktor yang telah dipilih lewat seleksi lelang Pemerintah Kabupaten. Setelah pembangunan selesai Ruang Terbuka Hijau (RTH) dalam pengelolaannya diserahkan kepada Pemerintahan Desa Kesambirampak." (Sumber: hasil wawancara dengan bapak H. Iwan Subakhti, ST selaku Kasi Perencanaan Dinas pada tanggal 03 Juli 2020 pukul 13.10 WIB di ruang kerja Dinas Perumahan dan Kawasan Permukiman).

Selain itu hal yang sama diungkapkan oleh Ibu Rike selaku pengelola kios produk unggulan Kecamatan Kapongan di Ruang Terbuka Hijau (RTH) Taman Lanceng:

"Dengan adanya Ruang Terbuka Hijau (RTH) yang dulunya hanya lapangan saja sekarang menjadi bangunan Taman publik yang menyediakan tempat bermain anak (setidaknya ada permainan yang non bayar kayak ayunan atau permaian edukasi) sehingga tidak perlu bayar kasihan mereka yang tidak punya uang. Juga dengan adanya kios yang menydiakan produk unggulan kecamatan hal ini dapat menunjang homeindustri masyarakat sehingga mereka yang awalnya penggangguran dapat berkerja dan membantu perekonomian keluarga. Maka perekeonomian masyarakat yang 
P-ISSN 2580 - 7781

E-ISSN 2615 - 3238

ada disekitar taman dapat meningkat." (Sumber: Wawancara pada tanggal 19 Juli 2020, pukul 19.30 WIB).

Menurut Bapak Dillis Roby Kurniawan,SSTP,M.Si selaku Sekcam Kapongan hasil wawancara dengan beliau mengungkapkan:

"Strategi agar pembangunan Ruang Terbuka Hijau (RTH) dapat dimanfaat oleh banyak orang khususnya warga Kecamatan Kapongan, maka pihak kami menggelar pasar rakyat setiap 1 bulan 1 kali, kemudian adanya jajanan traditional yang dijual di Taman tersebut, sehingga kami tidak menghilangkan budaya lokal yang ada. Adapun yang menyediakan jajan traditional mereka bergabung dalam kelompok Forum Komunikasi Intra Masyarakat (FKIM) ." (Sumber: Wawancara pada tanggal 20 juli 2020 pukul 09.30 WIB).

Setelah dilakukan penelitian dilapangan, terjadi kesenjangan dalam hal strategi. Masyarakat mengaku pembangunan Ruang Terbuka Hijau dalam hal sosialisasi awal hanya sebagian warga saja yang dilibatkan, informasi yang disampaikan belum sampai kepada sebagian masyarakat, sehingga masyarakat tidak bisa memanfaatkan keberadaan Ruang Terbuka Hijau (RTH) dengan efektif. Seperti apa yang telah disampaikan oleh Ibu Rina selaku masyarakat sekitar Ruang Terbuka Hijau (RTH) di Desa Kesambirampak:

"Untuk startegi seharusnya dengan dibangunkannya Ruang Terbuka Hijau Dinas terkait atau perangkat desa memberikan sosialisasi pemanfaatan ruang terbuka hijau kepada warga melalui kepala dusun diabantu ketua RT untuk memberikan pemahaman kepada kita. Pembangunan RTH agar bermanfaat sarana prasarananya terpenuhi tidak hanya setahun bagus kemudian jelek. Harus dipantau terus pengelolaannya agar barang yang disediakan pemerintah dapat berhasil guna."(Sumber: Wawancara pada tanggal 20 Juli 2019, pukul 16.30 WIB).

Menurut Bapak Suwito selaku kasi pertamanan Dinas Perumahan dan Kawasan Permukiman ditemui di ruang kerjanya:

"Kalau strategi dari pembangunan Ruang Terbuka Hijau kita lebih memnfaatakan masyarakat disekita untuk jualan di lokasi RTH sehingga dapat menunjang penghasilan rumah tangga mereka. Dan dapat mebuka lapangan perkerjaan bagi mereka yang sebelumnya menganggur. Adapun strategi yang dilakukan antara lain adanya 


\section{P-ISSN 2580 - 7781}

E-ISSN 2615 - 3238

pasar rakyat yang dilaksanakan 1 bulan 1 kali pada malam minggu, pentas seni bagi seniman yang ada di Situbondo, akan tetapi hal ini belum berjalan karena peminat seniman yang akan tampil di taman tersebut mereka lebih memilih untuk tampil di alun-alun dengan pertimbangan banyak pengunjung. Serta menghadirkan simpel puter tiap malam minggu sebagai layanan kepada masyarakat bidang catatan sipil, pembayaran pajak dll.” (Sumber: Wawancara pada tanggal 21 Juli 2020, pukul 09.30 WIB).

Berdasarkan hasil wawancara strategi pemanfaatan Ruang Terbuka Hijau (RTH) sudah jelas. Yaitu memberikan pelayanan kepada masyarakat baik segi bidang sosial, bidang ekonomi, bidang administrasi. Dari segi bidang sosial Ruang terbuka Hijau (RTH) Taman Lanceng Desa Kesambirampak Kecamatan Kapongan sebagai tempat interaksi antar warga sehingga saling mengenal satu sama lain sampai kepada budaya lokal yang ada di desa masing-masing, sebagai bentuk pengenalan atau melestarikan budaya masyarakat yang ada sehingga dapat mengenalkan kepada generasi muda dan masyarakat Kabupaten Situbondo serta sebagai alternatif sarana bermain anak-anak yang mudah dijangkau oleh masyarakat. Dari segi bidang ekonomi sebagai sarana peningkatan pendapat masyarakat dengan berjualan baik itu makanan siap saji maupun jajanan traditional dengan tujuan melestarikan kebudayaan lokal yang memberdayaan kelompok masyarakat FKIM yang dikelola oleh Badan Usaha Milih Desa Kesambirampak Kecamatan Kapongan. Dari segi bidang adminitrasi sebagai wadah pemerintah memberikan pelayanan masyarakat lewat simpel puter ( pelayanan catatan sipil, pembayaran pajak, pengurusan keadminitrasian yang dibutuhkan masyarakat yang mana mereka bisanya datang ke instansi maka dengan ini mereka cukup datang ke RTH/Taman Lanceng untuk mengurus kebutuhan pengadministrasian mereka sehingga tidak menggangu waktu bekerja mereka. Sebagaimana tabel kegiatan masyarakat pada pemanfaatan Ruang Terbuka Hijau (RTH) sebagaimana data dibawah ini :

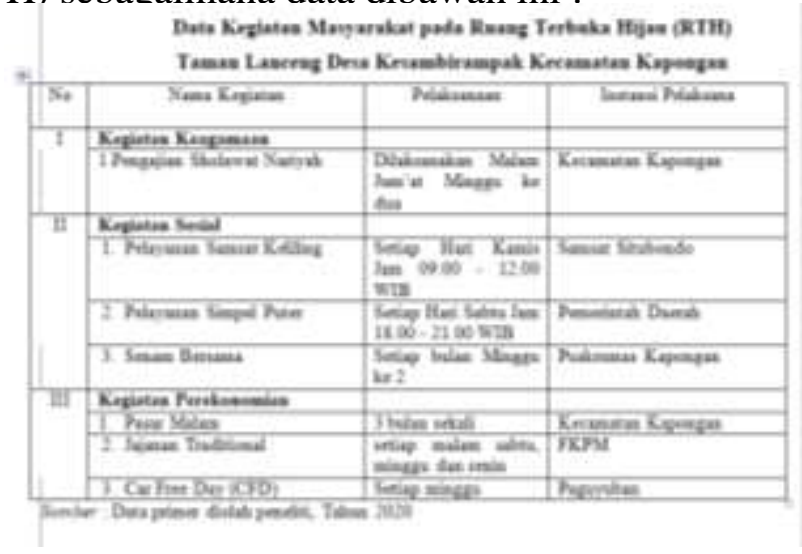


P-ISSN 2580 - 7781

E-ISSN 2615 - 3238

\section{Dampak Adanya Pembangunan Ruang Terbuka Hijau}

Pengembangan dan peningkatan Ruang Terbuka Hijau (RTH), memberikan kesempatan kerja khususnya bagi masyarakat sekitar Taman Desa Kesambirampak. Berdasarkan data yang kami peroleh selama melakukan penelitian, diketahui bahwa masyarakat sekitar Ruang Terbuka Hijau (RTH) membuka berbagai usaha. Melalui kebijakan Pemerintah Daerah yang dibantu oleh Pemerintah Desa, memberikan kesempatan pada masayarakat untuk membuka berbagai macam usaha yang secara tidak langsung juga memberikan kesempatan berwirausaha bagi masyarakat sekitar lokasi Ruang Terbuka Hijau (RTH) taman lancing Desa Kesambiran Kecamatan Kapongan.

Perubahan yang terjadi pada masyarakat Kabupaten Situbondo yang mengalami proses pembangunan Ruang Terbuka Hijau (RTH), merupakan suatu gejala wajar jika dilihat dari arti pembangunan yang merupakan usaha sadar, terencana dan terus-menerus yang dilakukan oleh suatu bangsa, negara dan pemerintah menuju masyarakat yang modern untuk memperbaiki kualitas hidup masyarakat melalui pemanfaatan yang dimiliki.

Perubahan persepsi pada masyarakat Kabupaten Situbondo khususnya masyarakat sekitar Ruang Terbuka Hijau (RTH) terjadi apabila terdapat perbedaan pandangan masyarakat terhadap adanya Ruang Terbuka Hijau (RTH) dan perubahan pandangan tersebut dapat mengarah pada arah yang positif dan neggatif.

Dari hasil penelitian dengan menggunakan metode wawancara terhadap masyarakat sekitar Ruang Terbuka Hijau (RTH), maka diperoleh data yang menyatakan bahwa terjadi perubahan presepsi yang mengarah pada arah positif. Seperti yang diungkap oleh Mukhlis selaku plt. Kepala Desa Kesambirampak:

“Alhamdulillah dengan adanya Ruang Terbuka Hijau (RTH) ini, membuat kami tidak bingung lagi mencari pekerjaan. Karena banyak pekerjaan yang bisa kami lakukan, misalnya membuka warung makanan siap saji maupun jajan traditional desa kami dan juga hasil karya warga ."

(Tanggal 9 Juli 2020, Pukul 10.00 WIB)

Masyarakat sekitar Ruang Terbuka Hijau (RTH) mengalami perubahan kearah yang baik dengan adanya Taman kota saat ini. Dikarenakan masyarakat 
P-ISSN $2580-7781$

E-ISSN 2615 - 3238

Desa Kesambirampak sendiri merasa ada perubahan pada daerahnya yang dulunya sepi sekarang menjadi lebih ramai. Hal ini menguntungkan para pedagang dalam menjual. Selain itu, menurut masyarakat Desa Kesambirampak sendiri yang berprofesi sebagai petani, adanya Ruang Terbuka Hijau (RTH) dapat membantu perekonomian mereka yang awalnya hanya mengandalkan buruh tani atau hasil panen yang tidak menentu akan tetapi sekarang dengan adanya Ruang Terbuka Hijau malam harinya kami bisa berjualan untuk menyambung hidup. Hal ini juga salah satu dampak adanya Ruang Terbuka Hijau (RTH) “Taman Lanceng” yang berada di Desa Kesambirampak Kecamatan Kapongan, sesuai dengan pendapat Bapak Gofur selaku ketua paguyuban :

"Ruang Terbuka Hijau (RTH) ini sangat banyak manfaatnya bagi kami, salah satunya yang paling terlihat awal adanya taman ini masyarakat tidak perlu jauh datang ke alun-alun disini mereka sudah bisa menemukan hiburan " (tanggal 9 Juli 2020, Pukul 09.00 WIB)

Hal ini juga senada dengan yang disampaikan oleh P. Mis yaitu:

“ Dengan dibangunnya Taman ini mas, yang awalnya lapangan ini kumuh sekarang menjadi bagus dan menarik serta tidak ada warung-warung berjejer dipinggir jalan sekarang terpusat di sebelah timur taman ini" (tanggal 10 Juli 2020, Pukul 12.00 WIB)

Dengan demikian, lokasi suatu Ruang Terbuka Hijau (RTH) taman lancing Desa Kesambirampak Kecamatan Kapongan dapat menjelaskan jaringan regional atas kota-kota yang saling berhubungan. Dalam dunia usaha yang mana Desa Kesambirampak ini menghasil produk mangga. Berdasarkan jejak-jejak historis jaringan regional yang diakibatkan aktivitas Ruang Terbuka Hijau (RTH) Oleh karena itu Ruang Terbuka Hijau (RTH) yang di Desa Kesambirampak diharapkan dapat memberikan dampak yang baik bagi masyarakat sekitar, utamanya dalam bidang ekonomi masyarakat Desa Kesambirampak.

Ramainya para pengunjung di Ruang Terbuka Hijau membuat suasana daerah taman menjadi ramai. Hal ini berbeda sekali sebelum dibangunnya Ruang Terbuka Hijau (RTH) ini. Tidak hanya itu bangunan di sekitar Ruang Terbuka Hijau (RTH) pun sekarang terlihat bagus dan mewah dibandingkan sebelumnya. Hal ini menandakan keadaan ekonomi masyarakat Desa Kesambirampak mulai 
P-ISSN 2580 - 7781

E-ISSN 2615 - 3238

meningkat dengan adanya Ruang Terbuka Hijau (RTH). Banyaknya dampak yang terjadi karena adanya Ruang Terbuka Hijau (RTH) ini juga dirasakan oleh Suparto, warga Desa Kesambirampak.

"Dampaknya sangat banyak sekali, coba anda lihat! Awalnya lapangan ini kumuh sekarang tertata rapi juga mereka yang berdagang sudah ada kios masing-masing serta tambahan gerobak bagi yang tidak kebagian kios. Mereka melertarikan jajanan traditional yang sudah mulai hilang dengan persaingan jajan yang modern sekarang ini. Hal ini akan memberikan penghasilan tambahan bagi para masyarakat yang awal mencari nafkah di sektor pertanian sekarang bisa juga berdagang di malam harinya"

(Tanggal 10 Juli 2020, Pukul 17.00 WIB)

Secara ekonomi kota Ruang Terbuka Hijau (RTH) sangat menonjol pada akhir-akhir ini karena dapat menciptakan perdagangan dan tempat wisata. Perkembangan suatu taman yang sekarang menjadi kebutuhan masyarakat dengan padatnya penduduk maka dibutuhkan Ruang Terbuka Hijau (RTH). Tempat bertemunya masyarakat atau manusia tidak bisa dilepaskan dengan perdagangan, dan sudah barang tentu perkembangan perdagangan juga sangat terkait dengan peran dan fungsi Taman. Bahkan, Max Weber mengatakan, bahwa perdagangan merupakan variabel yang menentukan dalam perkembangan sebuah kota.

Ruang Terbuka Hijau (RTH) rupanya menduduki posisi penting dalam proses dinamika pertemuan budaya, karena melalui ruang ini dihubungkan jalinan budaya antara wilayah dan sebagai aicon desa untuk mengenal budaya desa tersebut. Ruang Terbuka Hijau ( RTH) yang posisinya dipinggir jalan pantura merupakan tempat strategis dalam mengenalkan budaya atau makanan khas daerah itu sendiri. Ini merupakan kesempatan yang sangat baik dan emas jika dapat memanfaatkan dengan sebaik-baiknya. Maka pengelolaan Ruang Terbuka Hijau (RTH) betul- betul dikelola dengan baik bersama Pemerintahan Daerah, Pemerintahan Desa serta masyarakat sekitar bersama-sama berkerjasama agar pembangunan Ruang Terbuka Hijau (RTH) yang telah dibangun oleh Pemerintahan Daerah menemui hasil yang maksimal bagi kehidupan masyarakat daerah khusus masyarakat desa setempat. Ruang Terbuka Hijau (RTH) di sinilah interaksi budaya dengan segala implikasinya terjadi. Interaksi budaya ini telah memunculkan kelompok-kelompok sosial dari berbagai etnis dan membentuk 
P-ISSN $2580-7781$

E-ISSN 2615 - 3238

kampung-kampung etnis tertentu dengan kulturasi budaya mereka yang berkembang di sekitar taman. Maka Dari segi perekonomian masyarakat Desa akan meningkat pula. Sebagaimana data dari 17 Kecamatan se Situbondo yang diungkapkan oleh Bapak Yoyok Mulyadi selaku Wakil Bupati bahwasanya:

“ Menurutnya pertumbuhan ekonomi Kecamatan Kapongan mencapai 6,93 persen. Sebaliknya, petumbuhan ekonomi paling rendah di Kecamatan Arjasa, yaitu 3,20 persen., dirinya sangat mengapresiasi pertumbuhan ekonomi di Kecamatan Kapongan. Saat ini, perekonomian masyarakat bergerak tumbuh, salah satunya disebabkan karena dipengaruhi tumbuhnya ekonomi kreatif. Tumbuhnya usaha-usah kecil tersebut, menyebabkan masyarakat memiliki penghasilan tambahan. Masyarakat yang sebelumnya jadi pengangguran, kini sudah mulai memiliki pekerjaan secara mandiri. Pertumbuhan ekonomi cukup tinggi di Kecamatan Kapongan, tentu tidak lepas dari upaya Pemkab Situbondo memberikan fasilitas tempat berjualan. Setiap malam minggu, pedagang berjualan di RTH atau Ruang Terbuka Hijau. Saat ini kata Yoyok, Pemkab juga sudah menyiapkan Ruang Terbuka Hijau di Kecamatan Arjasa. Sebagai kawasan dengan pertumbuhan ekonomi terendah, Wabup meminta pihak Kecamatan harus ikut mendorong warganya, agar meniru pertumbuhan ekonomi di Kecamatan Kapongan. (https://www.bhasafm.co.id/pemerintahan/pertumbuhan-ekonomi,13

Februari 2019)

\section{KESIMPULAN}

Dalam Penelitian ini dapat disimpulkan bahwa pembangunan Ruang Terbuka Hijau (RTH) Taman Lanceng Desa Kesambirampak Kecamatan Kapongan telah tepat sasaran yang bertujuan lingkungan yang padat penduduk mendapatkan pembangunan berkelanjutan yang dapat meningkatkan taraf kehidupan masyarakat yang lebih baik.

Secara ekonomi kota Ruang Terbuka Hijau (RTH) sangat menonjol pada akhir-akhir ini karena dapat menciptakan perdagangan dan tempat wisata. Ruang Terbuka Hijau (RTH) merupakan tempat bertemunya masyarakat atau manusia tidak bisa dilepaskan dengan perdagangan, dan sudah barang tentu perkembangan perdagangan juga sangat terkait dengan peran dan fungsi Taman. Bahkan, Max Weber mengatakan, bahwa perdagangan merupakan variabel yang menentukan dalam perkembangan sebuah kota. 
P-ISSN $2580-7781$

E-ISSN 2615 - 3238

Ruang Terbuka Hijau (RTH) rupanya menduduki posisi penting dalam proses dinamika pertemuan budaya, karena melalui ruang ini dihubungkan jalinan budaya antara wilayah dan sebagai aicon desa untuk mengenal budaya desa tersebut. Ruang Terbuka Hijau ( RTH) yang posisinya dipinggir jalan pantura merupakan tempat strategis dalam mengenalkan budaya atau makanan khas daerah itu sendiri. Ini merupakan kesempatan yang sangat baik dan emas jika dapat memanfaatkan dengan sebaik-baiknya. Maka pengelolaan Ruang Terbuka Hijau (RTH) betul- betul dikelola dengan baik bersama Pemerintahan Daerah, Pemerintahan Desa serta masyarakat sekitar bersama-sama berkerjasama agar pembangunan Ruang Terbuka Hijau (RTH) yang telah dibangun oleh Pemerintahan Daerah menghasilkan hasil yang maksimal bagi kehidupan masyarakat daerah khusus masyarakat desa setempat. Ruang Terbuka Hijau (RTH) di sinilah interaksi budaya dengan segala implikasinya terjadi. Interaksi budaya ini telah memunculkan kelompok-kelompok sosial dari berbagai etnis dan membentuk kampung-kampung etnis tertentu dengan kulturasi budaya mereka yang berkembang di sekitar taman.

\section{DAFTAR PUSTAKA}

Bintarto, 1986, Urbanisasi dan Permasalahannya: Ghalia Indonesia, Jakarta.

Budiharjo, E., 2005, Kota Berkelanjutan: Penerbit Alumni, Bandung.

Dahlan, N, E., 2004, Membangun Kota Kebun Bernuansa Hutan Kota: Institut Pertanian Bogor, Bogor.

Darmawan, E., 2006, Teori dan Kajian Ruang Publik Kota: Badan Penerbit Universitas Diponegoro, Semarang.

Hakim, R., dan Utomo, H., 2003, Komponen Perancangan Arsitektur Lansekap, Prinsip - Unsur dan Aplikasi Desain: Penerbit Bumi Aksara, Jakarta. Jayadinata, T, J., 1992, Tata Guna Tanah dalam Perencanaan Pedesaan Perkotaan dan Wilayah: Institut Teknologi Bandung, Bandung.

Nazaruddin, 1994, Penghijauan Kota: Penerbit Swadaya, Jakarta. Dikutip dari Laporan Tugas Akhir Reza Fauzi Ardian, 2013, Strategi Penataan Ruang Terbuka Hijau Wilayah Perkotaan sebagai Pendukung Struktur Ruang, Jurusan Teknik Planologi, Universitas Pasundan, Bandung.

Nirwono, J., dan Ismaun, I., 2011, RTH 30\%! Resolusi (Kota) Hijau: Gramedia Pustaka Utama, Jakarta. 
P-ISSN $2580-7781$

E-ISSN 2615 - 3238

Nuranto, Galih Pratama 2013. Pemberdayaan Masyarakat Petani Padi Organik (Studi Pemberdayaan Paguyuban Petani Barokah Desa Ketapang Kecamatan Sususkan Kabupaten Semarang). Journal of Non Formal Education And Community Empowerment NFECE 2 (1) (2013)

Purnomohadi, N., 2006, Ruang Terbuka Hijau sebagai Unsur Utama Tata Ruang Kota: Direktorat Jenderal Penataan Ruang, Kementrian PU, Jakarta

Rapuano, M., and Brooks, E., 1964, Open Space in Urban Design: The Cleveland Development Foundation, Cleveland, Ohio. Dikutip dari Laporan Tugas Akhir Reza Fauzi Ardian, 2013, Strategi Penataan Ruang Terbuka Hijau Wilayah Perkotaan sebagai Pendukung Struktur Ruang, Jurusan Teknik Planologi, Universitas Pasundan, Bandung.

Republik Indonesia, 2007, Direktorat Jenderal Penataan Ruang Tahun 2007, Departemen Pekerjaan Umum tentang Pedoman Penataan Ruang Kawasan Perkotaan.

Republik Indonesia, 2009, Peraturan Daerah Provinsi Jawa Barat No. 3 Tahun 2009 tentang Garis Sempadan Jalan.

Republik Indonesia, 1987, Keputusan Menteri Pekerjaan Umum No. 378 tentang Petunjuk Perencanaan Tebal Perkerasan Lentur Jalan Raya dengan Metode Analisa.

Republik Indonesia, 2007, Peraturan Menteri Dalam Negeri No. 1 Tahun 2007 tentang Penataan Ruang Terbuka Hijau di Kawasan Perkotaan.

Republik Indonesia, 2008, Peraturan Menteri Pekerjaan Umum No. 5 PRT/M/2008 tentang Pedoman Penyediaan Pemanfaatan Ruang Terbuka Hijau di Kawasan Perkotaan.

Republik Indonesia, Rencana Detail Tata Ruang Kota Bandung Tahun 2015-2035. Republik Indonesia, Rencana Tata Ruang Wilayah Kota Bandung Tahun 2011- 2031.

Republik Indonesia, 2007, Undang Undang No. 26 Tahun 2007 tentang Penataan Ruang.

Putra Wijaya, 2013. Analisis Pembanguan Ruang Terbuka Hijau (RTH) Publik di Jakarta Timur

Rivino Kalesan, 2016. Efektifitas Ruang Terbuka Hijau Publik Kecamatan Sario Kota Manado

Wuri Setyani, 2017. Analisis Ruang Terbuka Hijau dan Kecukupannya di Kota Depok

Sulistiyani, ambar Teguh, 2017. Kemitraan dan Model-model pemberdayaan. Yogyakarta. Gavamedia

Moleong Lexy J, 2012, Metodologi Penelitian Kualitatif, Bandung:Remaja Rosdakarya. 